\title{
Risk Assessment-the Key to More Security? Factors, Tools, and Practices in Dealing with Extremist Individuals
}

\author{
Katrin Höffler ${ }^{1} \cdot$ Miriam Meyer $^{1} \cdot$ Veronika Möller $^{1}$
}

Accepted: 16 August 2021 / Published online: 3 January 2022

(c) The Author(s) 2022

\begin{abstract}
In recent years, risk assessments for violent extremism have attracted great interest from both scholars and practitioners, and many assessment tools have been developed. After a critical review of this development, the paper examines differences and similarities between the indicators of various violent extremist risk assessment tools and checklists. Based on an interview study with 34 experts in the field of Counter Violent Extremism and 24 (formerly) radicalized persons from the right-wing radical and Salafi-Jihadist spectrum, risk factors were identified and the findings merged and compared with already existing risk assessment tools. The paper will present results especially regarding the risk signals' occurrence and applicability in the German context. One key finding is that existing assessment tools insufficiently take into account personal contacts in the radicalization process. Thus, the paper-based on the results of a social network analysis-draws attention to the potential and importance of networks. The paper concludes by outlining the potential of risk assessment, suggesting improvements, and raising awareness of the limits and deficits of these tools. The paper thus scientifically addresses the challenge of more security through efficient risk assessment and management. It offers a list of radicalization process characteristics (ARISNA: Assessment of Radicalized Individuals including Social Network Analysis), which is designed to help users analyze the risk of radicalization based on concrete traits of a person and their environment.
\end{abstract}

Keywords Radicalization · Extremism · Terrorism · Risk assessment · Social network analysis

\section{Introduction}

Radicalization is increasing around the world, in some cases leading to violent attacks. To study and prevent this phenomenon, a new area of research has emerged under the headline of (Violent) Extremist or Terrorist Risk Assessment. This research, part of the broader category of extremism and terrorism research, is dedicated to assessing risks specifically in the extremist milieu. A rising number of diverse risk assessment instruments, checklists, and

Katrin Höffler

lehrstuhl.hoeffler@jura.uni-goettingen.de

1 Georg-August-Universität Göttingen, Goßlerstraße 15a, 37073 Göttingen, Germany 
(computer-aided) tools have been developed, the risk indicators of which are derived (also methodologically) in different ways (cf. also Meyer, 2022); they are based, among other things, on literature analyses ("top-down," see, e.g., VERA, Pressman, 2009), including "reviews of the available empirical studies and case experience" (see Meloy \& Yakeley, 2014; for TRAP-18; also see Meloy et al., 2012; Meloy et al., 2015; Meloy \& Gill, 2016), on expert consultation (e.g., VERA-2, see Pressman \& Flockton, 2012, VERA-2R, see Pressman et al., 2018, Sadowski et al., 2017 and EvIs, see Ullrich et al., 2019), or "casework with UK convicted terrorists, cross-referenced to the literature where this provides corroboration, but essentially evidenced by the offenders themselves" (e.g., ERG22+, s. Lloyd \& Dean, 2015). However, due to low base rates ("rare events," which are scattered globally), all instruments lack broad empirical foundations; a true evaluation of the instruments is (still) largely absent-in fact it may be fundamentally unfeasable (see Scarcella et al., 2016; on the validation history and interrater reliability of TRAP-18, see RMA, 2019 and Guldimann \& Meloy, 2020; on interrater reliability of ERG22+, see Powis et al., 2019a, 2019b; on its construct validity, see Powis et al., 2019a, 2019b). Users should always keep this in the back of their minds.

In our study at the Göttingen University, the following risk assessment instruments have been compared (Höffler \& Gatzmaga, 2018; Meyer, 2022):

- VERA-2R (Violent Extremist Risk Assessment, Pressman et al., 2018; Sadowski et al., 2017) and its "sister" instrument CYBERA aimed at online behavior (Pressman \& Ivan, 2016)

- ERG22 + (“Extremist Risk Guidance," Lloyd \& Dean, 2015)

- IVPG ("Guidance for Identifying People Vulnerable to Recruitment into Violent Extremism," Cole et al., 2016; Egan et al., 2016),

- TRAP-18 (“Terrorist Radicalization Assessment Protocol," Meloy, 2017; Meloy et al., 2015), which was specially developed for lone offenders

- MLG ("Multi Level Guidelines", Cook et al., 2013; Cook, 2014; Hart et al., 2017 for MLG version 2), which are not extremism-specific but are geared towards group-based violence

- EvIs ("Evaluation Criteria for the Prevention of Islamism," Ullrich et al., 2019), which were specially developed for Germany.

A view at the design structure and objectives of the instruments reveals that TRAP-18 uses a developmental model combined with warning signals to focus on potential individual perpetrators of an extremist attack; VERA-2R aims to assess the risk of extremist acts of violence with 34 indicators; ERG22+, on the other hand, aims to assess the risk of all extremist-motivated acts (see the comparative analysis in Meyer, 2022). In contrast, the IVPG tool, which is geared towards warning signals that trigger an acute need for action, similar to TRAP-18, is intended to screen for vulnerability (Egan et al., 2016), i.e., to detect susceptibility to recruitment by extremist groups, but it is not designed to assess violent extremism (Cole et al., 2016). The EvIs are also not intended to assess extremist risks. Rather, when already radicalized persons participate in intervention programs, the tool is used to "measure" changes in radicalization characteristics over the course of the intervention (Ullrich et al., 2019).

Building on findings from extremist risk assessment research, this article uses a qualitative study to examine which of the risk assessment instruments' indicators are applicable to radicalization processes in Germany. It will single out the most significant characteristics for a detailed treatment. The focus will not be one of predictability of terrorist attacks but will be on signal categories characterizing the radicalization process. As part of the RadigZ research network (see "Acknowledgements"), this paper follows the definition of radicalization as a development of attitudes, values, and actions towards extremism, which is again 
characterized by attitudes, values, and actions significantly deviating from sociopolitical norms of a system and aiming to establish new norm systems (Beelmann \& Lehmann, 2020).

The results have been combined into a list of radicalization process characteristics (ARISNA: Assessment of Radicalized Individuals including Social Network Analysis), which is not intended as a prediction tool in the narrow sense (readers looking for a simple risk assessment tool providing individual risk scores will be disappointed) but a tool to help users identify individual and environmental characteristics of relevance for radicalization processes.

\section{Methodology}

\section{Data Access and Method}

Our study at the Göttingen University employs two different field approaches, the findings of which are analyzed in conjunction. On the one hand, 34 expert interviews and a focus group of professional observers in the field of religiously motivated and right-wing extremism from probation services, the judiciary, various security authorities, and civil actors (e.g., prevention projects) were conducted and analyzed. On the other hand, 24 biographical-narrative interviews were conducted with formerly or still radicalized persons from the right-wing as well as the SalafiJihadist spectrum. These interviews took place mainly, but not exclusively, in various German prisons. At the same time, this means that not all interviewees were convicted offenders. While the expert interviewees working on the area of religiously motivated radicalization and extremism significantly outnumber those working on the right-wing area (24 exclusively on religiously motivated vs. 6 exclusively on right-wing, three interviews on both phenomena, and one interviewee working independent of ideologies but referring to Islamist radicalization as well), this ratio was inverted with respect to interviews with (formerly) radicalized persons; significantly more interviews were conducted with persons from the right-wing spectrum (87.5\% vs. $12.5 \%)$.

All interviews were evaluated in terms of qualitative content analysis (see Mayring, 2015; Kuckartz, 2018). The interview analysis regarding (formerly) radicalized persons was supplemented by structural and analytical aspects of the MIVEA-method (German: "Methode der idealtypisch vergleichenden Einzelfallanalyse" (Bock, 1984, 2008))—a structured approach to evaluate criminogenic conditions in an offender's life ${ }^{1}$ —as well as a subsequent egocentric social network analysis. The focus of this is on displaying a person's contacts and their relationship to the respondent in a structured manner to analyze the significance that certain persons play for individual radicalization processes. ${ }^{2}$ The egocentric network analysis' application to risk assessment in the radicalization context constitutes a novel, so far unused, research design. It was integrated into the project's interviews with the (formerly) radicalized persons: contacts of the interviewee during the time of their incipient radicalization were collected in a structured manner and drawn up on a so-called network map. In subsequent analysis, the contacts obtained were reduced to "action-relevant" contacts in order to exclude contacts from the analysis which can be assumed to have no/very little influence on the interviewee (for details on the methodological procedure, see Möller, 2020, 2022; Höffler et al., 2020; for a general discussion of the method, see, e.g., Burt, 1984, Campbell \& Lee, 1991, Bidart \& Charbonneau, 2011, Rau \& Höffler, 2020).

\footnotetext{
${ }^{1}$ Based on Göppinger (1983).

${ }^{2}$ For a detailed description of significance and implementation of egocentric network analysis in the field of risk assessment s. Rau 2017; Möller 2020, 2022.
} 


\section{Development of a List of Radicalization Process Characteristics (Personal, Situational, and Network Characteristics for Radicalization)}

To lay the groundwork for the coding-schemes of the qualitative interview content analysis, additional to literature analysis, the indicators from pre-existing risk assessment tools were extracted, compared, and grouped by focusing on similar aspects underlying the items (e.g., "need for excitement, comradeship, or adventure" in ERG22+and "driven by excitement, adventure" in VERA-2R). After the interviews were coded, the frequency of the coding allowed us to draw initial conclusions about the occurrence of the criteria in our samples. Some specific indicators such as "dependence on the virtual community" in TRAP-18 or indicators relating to terrorist training and resources (e.g., "tactical, paramilitary, explosive training" in VERA-2R) were not coded at all, i.e., did not occur in our interview sample. ${ }^{3}$ In a second step, the signals detected in the interviews were merged with further inductively derived characteristics and ranked according to their frequency and importance. Following a mixed methods approach, the results from expert and subject interviews were brought together and compared in a discursive manner (for detailed information on the triangulation of methods, see, for example, Flick, 2011). The most important characteristics (both in terms of frequent occurrence and qualitatively) of the interviews with (formerly) radicalized individuals and experts were then included in the list of radicalization process characteristics (ARISNA). ${ }^{4}$

Due to the design of the study, the presented criteria catalog is still in the early stages of its development; in particular, an evaluation of the catalog within a larger sample is reserved for follow-up studies. It can however-in conjunction with a social network analysisalready today serve as a checklist for practitioners in the true sense of the word, i.e., as a support tool when conducting individual risk assessment. It should be emphasized, however, that in order to consider an individual at risk in terms of radicalization, it is by no means necessary that all points of the list are checked off. Rather, as is the case for all prognoses, it is often isolated circumstances, which can spin the overall picture in a completely different direction, diametrically opposed to where all other criteria had been pointing at so far; to recognize this, to remain open for it, is a core challenge for all risk assessment practitioners (cf. Bock, 2017).

\section{Interviews with (Formerly) Radicalized Individuals Including Social Network Analysis (SNA) and Interviews with Experts: Most Frequent Characteristics}

In the following, the findings from expert interviews as well as interviews with (formerly) radicalized individuals will be presented thematically sorted. Most of the categories comprise several characteristic variables which cannot be considered separately but are connected to each other.

\footnotetext{
3 This is partly due to the fact that individual characteristics were actually not present in the interview material and can probably be explained by the selection of interview partners guided by our research questions: investigating the developmental process of radicalization. We thus did not focus solely on lone perpetrators (as addressed by TRAP-18), and our sample did not contain perpetrators of terrorist attacks. The questions within the expert interviews, too, were aimed at studying radicalization processes. Moreover, the expert interviews in particular showed that both terrorist attackers and lone perpetrators marked by TRAP18 are the exception.

4 The presentation of the findings will make clear on which group of interviews each finding is based.
} 


\section{Biography}

\section{Difficult Upbringing ${ }^{5}$}

Problematic upbringings run like a thread through the biographies of many extremistsboth religious and right-wing. The egocentric network analysis provides a first reference point for this: in less than half of the interviewed cases are family members named as "action-relevant" contacts at the time of a beginning radicalization. The lack of actionrelevant family members affected all interviewees who became radicalized after coming of age but also about $1 / 3$ of interviewees who were still adolescent at the time of radicalization (cf. Möller, 2022).

Strikingly frequent are mentions by both experts and radicalized individuals of a missing or difficult father figure during childhood and/or adolescence, i.e., the father is either completely absent, addicted, or the relationship with him is (very) problematic for other reasons (Meyer, 2022; Möller, 2022). Sometimes the father is particularly authoritarian (see especially Meyer, 2022) and/or refuses to give the love and affection desired by the child/adolescent. It is not uncommon for the upbringing of these individuals to be characterized by violent behavior from their custodians (see especially Möller, 2022).

A special shape such difficult upbringing can take is evident in many biographical self-characterizations of right-wing radicals, who report alienation from their own family through (multiple) stays in the foster care system, often over many years (see Möller, 2022). Such experiences often represent biographical breaks (see below "Losses and Breaks"), which are frequently numbed by excessive alcohol or drug consumption, compensated for by the use of violence, or overcome by joining groups that promise a feeling of belonging and security (see also below "Search for belonging").

Difficult family circumstances can, but need not, be linked to a poorer socioeconomic status (see Meyer, 2022; Möller, 2022). Growing up in financially weaker families and/or socially deprived neighborhoods can be an additional burdening factor. It is important to note, however, that especially among those who have no connection to the criminal milieu (see below "Criminal History and Substance (Ab)use" for more information on this group), no correlation can be assumed with regard to difficult social conditions and radicalization.

\section{Victimization Experiences ${ }^{7}$}

In particular, interviewees from the right-wing extremist spectrum experienced victimization to a high degree in childhood and adolescence (Möller, 2022; occasionally also described by experts regarding both phenomena, see Meyer, 2022). Physical violence by the own parents - especially the father-but also by other custodians, such as kindergarten and school teachers, or domestic helpers, is reported frequently (see Möller, 2022). In these

\footnotetext{
${ }^{5}$ Found similarly in EvIs (Ullrich et al., 2019) [German: "Schwierige familiäre Verhältnisse/Beziehungen"]; VERA-2R (Pressman et al., 2018; Sadowski et al., 2017) partly covers this aspect in "Personal history" as part of the "Additional indicators.".

6 Action-relevant contacts were determined using MIVEA and the strong-tie index (cf. Rau 2017; for the concept of strong-ties, see Granovetter 1975) to exclude people who have little or no influence on the individual.

7 Similarly, listed in the first version of MLG (Cook, Hart, and Kropp 2013) as "Problems resulting from victimization"; as a certain form of victimization, "Sexual assaults" [German: "Sexuelle Übergriffe"] listed in EvIs (Ullrich et al., 2019); violence experience also included in "Personal history" as part of the "Additional indicators" VERA-2R (Pressman et al., 2018; Sadowski et al., 2017).
} 
situations, children and adolescents experience that conflicts are resolved with violence and that punishment is carried out through physical violence but also that stress in adults can result in violence against the weaker (ibid.). In addition, sexual abuse experiences can also shape life, especially when confidants are the perpetrators or when the latter do not believe the children/adolescents or deny them the support they need to cope with the experience (ibid.). Further, experiences of bullying in a school context and the lack of help and/ or attention from teachers are also experienced as victimization. If the bullying perpetrators have a migrant background or if this is assumed by the bullying victims, it can lead to the development or consolidation of dichotomous thinking with a clear definition of the enemy, on the one hand, and, on the other hand, offer right-wing groups a simple "way in" by defending the bullying victim (usually through massive violence) and thereby strengthening the victims ties to the group (ibid.).

Experts, similarly, reported neglect, disregard, and physical violence by family members (mostly by the father, also against the mother) for persons from the radicalized Islamist spectrum (Meyer, 2022).

\section{Losses and Breaks ${ }^{8}$}

Many biographies contain breaks whose significance in the radicalization process is mentioned especially in the expert interviews (in detail Meyer, 2022; see also Möller, 2022). Breaks are understood to be various formative experiences, but above all losses anchored in the family sphere, such as the death of a family member, the divorce of the parents, or the complete disintegration of the family (Meyer, 2022; Möller, 2022). But also, other, supposedly less drastic events, such as a change of school or a move, separation from a partner, or the withdrawal of a friend can cause coping problems and as such can present "ruptures" (see Meyer, 2022; Möller, 2022). Triggers for these crises do not necessarily have to be recognized as breaks (Meyer, 2022). This is how situations can arise which are perceived as a heavy burden or even (acute) crisis by the individuals and which provide the breeding ground for radicalization.

\section{Social Contacts}

\section{Social Contacts at the Beginning of the Radicalization Process-Insights from Social Network Analysis}

Surprisingly, social contacts receive relatively little attention in extremism-specific risk assessment instruments; they are therefore of particular interest for the present research project. To fill this gap, an egocentric network analysis was integrated into the project's interviews with the (formerly) radicalized persons, a novel approach not previously systematically undertaken in extremist research (see under point 2. a). After the above-mentioned reduction of the named contacts to the action-relevant alteri, a heterogeneous distribution of different groups of social contacts (family, friends, acquaintances) in the network of radicalized persons was observed (Möller, 2022): The distribution of radical and nonradical alteri in the contact network of the interviewees was heterogeneous. Here it is

\footnotetext{
${ }^{8}$ Partly contained in the set of indicators "Dealing with critical life events" [German: "Umgang mit kritischen Lebensereignissen"] and "acute life crisis" [German: "Akute Lebenskrise"] in EvIs (Ullrich et al., 2019); also partly addressed by "Personal grievance and moral outrage" in TRAP-18 (Meloy 2017; Meloy et al., 2015) and "Transitional periods" in ERG22 + (Lloyd and Dean 2015).
} 
noticeable that a comparatively small proportion of people with equally radical attitudes can be found in the core family (21\%) and among relatives (15\%). Friends (41\%), work colleagues $(40 \%)$, and acquaintances $(55 \%)$, on the other hand, display significantly higher shares of radical world views. With regard to the duration of the contacts, it is also interesting that radical contacts have existed on average for a shorter period of time compared with an interviewee's other contacts. The majority of the interviewees' partners with radical views and roughly one-third of friends with such views were introduced to the interviewee while they were already part of a radical milieu or shortly before entering such milieu (ibid). Still, they exerted "action-relevant" influence on the individual. This is all the more remarkable because there was slightly less personal contact with these contacts than with the non-radical alteri. The lack of personal contact is neutralized, however, by the additional interaction possibilities offered by internet and/or telephone, which in particular increases the overall frequency of contact with like-minded radicalized persons via telephone calls and chats. The significance that other radicalized persons have for the interviewee despite contact limitations is also shown, however, by the fact that on average, more levels of relationship ${ }^{9}$ are realized between them than between the interviewee and his or her non-radicalized contacts (see Möller, 2022 for more details).

The results of egocentric network analysis, however, also made it clear that not in all cases do action-relevant, already radicalized persons accompany or shape the radicalization process from the very beginning (see Möller, 2022). This also indicates that these contacts may only become more important as radicalization progresses or may even be established only later within the "milieu." On the other hand, however, it was possible to find personal networks that are action-relevant and are composed exclusively of people who have already become radicalized (ibid.). What was striking about these networks was the above-average male dominance of the contacts, coupled with a below-average network size (see Möller, 2022 for more details).

\section{Contact with Other Radicalized Person(s) $)^{10}$}

Both the network analysis (cf. Möller, 2022) and the interviews with (formerly) radicalized individuals and experts show that radicalized persons without like-minded radical social contacts are an absolute exception. Friends and acquaintances often belong to the same radical circles (or are found there) and are accordingly often involved in violent actions shaped by a joint ideology or arising from a group dynamic (ibid.). In particular, direct contact with violent extremists can strengthen one's own readiness to use violence for the group and/or the ideology — by emulating the others as role models, by wanting or having to prove oneself, or by following a supposedly justified fascination with violence and need for adrenaline (ibid.).

For radical right-wing view, the egocentric network analysis (Möller, 2022) shows that action-relevant family members for some adolescents consist exclusively of persons with

\footnotetext{
9 The measure for this was the multiplexity of the relationships. Multiplex relationships are present when several relationship levels merge between the ego and the alteri, e.g., material and/or immaterial support merge with joint celebrations.

10 See similarly in EvIs "Maintains contacts with radicalized, social environment" [German: "Pflegt Kontakte zu radikalisiertem, sozialen Umfeld"] (Ullrich et al., 2019); partly also in VERA-2R (Pressman et al., 2018; Sadowski et al., 2017) "Personal contact with violent extremists" and "Network (family, friends) involved in violent action" as well as in CYBERA (Pressman and Ivan 2016) with "Is affiliated with an online group/social media promoting terrorist violence" and "establishes friendship bonds, networks other violent extremists online"; also in IVP (Cole et al., 2016; Egan et al., 2016) "Negative peer influence" and "Contact with known recruiters and extremists".
} 
right-wing extremist views. Neutral family members or those with a different political orientation therefore had no relevant influence on these adolescents at the time of beginning radicalization. In addition, family history can also shape the views and attitudes of the children and adolescents early in life (ibid.): Grandfathers and uncles who fought for Germany in the Wehrmacht or were members of the SS are glorified; the father is envied for having been part of the Hitler Youth. The statements of these family members about the Third Reich are not questioned and neither are evaluations of current events and proposed solutions for (perceived) problems. Rather, they are eagerly absorbed and thus integrated into the individual's own world view early in life. As far as available, Nazi memorabilia are passed down within the family with great care, and the own family history is proudly held up (ibid.).

In contrast, Islamist radicalization rarely develops from a radical Islamist family background. Even if siblings sometimes play a role in the radicalization process, it is primarily friends and (new) acquaintances or specific recruiters who are the decisive players in the radicalization process (Meyer, 2022; Möller, 2022). Recruiters make targeted contacts with vulnerable individuals, for example, in the periphery of mosques and attract them with the offer of (spiritual, but also material) support and answers to (religious) questions, as well as with the offer of belonging to a community. "(...) this person who was at the mosque on that day, and how he spoke to me. [...] At that moment I thought, this is perfect, really. I felt happy, I could talk about all my problems, we talked for hours" (ID021). ${ }^{11}$ This is also confirmed by the findings of the network analysis. No action-relevant, radicalized family members could be observed in the networks of the Salafi-Jihadist interviewees at the time of their beginning radicalization (cf. Möller, 2022).

In addition to local contacts, online contacts also play a special role in the radicalization process. Networking via the internet in Islamists chat groups and forums throughout Germany and internationally is particularly common for religiously motivated radicalized persons who are less socially established or who cannot find local access to other radicalized persons (see also Höffler et al., 2020). Similarly, individuals from the right-wing spectrum find "comrades" online, network with them in online groups, and arrange joint real-world actions (Möller, 2022).

\section{Delinquency and Substance (Ab)use}

\section{Criminal History ${ }^{12}$}

An overall view of the expert interviews (Meyer, 2022) reveals that among the religiously motivated radicalized individuals exists a subset of people with a criminal past, ranging from petty criminals to repeat offenders, predominantly theft and robbery, bodily injury and drug crimes. Particularly the latter, drug use and sale are widespread in this subset (see also "Substance abuse"); outside of this subset, the criminal past of the radicalized individuals seems to be very diverse (including no criminal history at all); a general prevalence of individuals with a criminal record cannot be found.

\footnotetext{
11 For more detailed descriptions of the cases, see Möller 2022.

12 Also listed as an indicator in ERG 22 + (Lloyd and Dean 2015); aspects of criminal history in VERA-2R (Pressman et al., 2018; Sadowski et al., 2017) "Prior criminal violence" and more general also "Criminal history" as part of the "Additional indicators"; also "Nonviolent criminal behavior" in MLG (Cook, Hart and Kropp 2013) but not anymore in version 2 (see Hart et al., 2017); "criminal violence" in TRAP-18 (Meloy 2017; Meloy et al., 2015).
} 
While some experts observed criminality declining with religiously motivated radicalization, others emphasized that this cannot be assumed, especially regarding violent crimes (Meyer, 2022). The group of "petty criminals" and repeat offenders also includes those who have already shown an increased readiness to use violence before radicalization and who do not abandon this readiness to use violence in the course of radicalization but rather try to justify it through ideology (Meyer, 2022), for example, by violently affirming or establishing the honor or status of the group or supporting the financing of the group (Möller, 2022). In contrast, according to expert interviews, people who were not known to be violent before radicalization only resort to violence in exceptional cases in the course of radicalization but rather commit offenses punishable under § 89a German Criminal Code (preparation of serious violent offense endangering state) and § 129a German Criminal Code (forming terrorist organizations; Meyer, 2022).

Crime on the right-wing extremist spectrum also occurs within a wide range of offenses and often at a very young age (reaching from offenses of defamation and property crimes to violent crimes, drug offenses, and gun possession charges but also offenses against public order or endangering the democratic constitutional state; Meyer, 2022; Möller, 2022). In contrast to the religiously motivated spectrum, ideologically motivated violent crimes are a key feature of right-wing radicalization (see Meyer, 2022; Möller, 2022). The interviews with (formerly) radicalized individuals reveal that pre-existing inclinations towards violence are now often ideologically directed and channeled by group dynamics (see Möller, 2022). Acts of violence are directed against all (groups of) persons perceived and/or defined as outgroups. They are physically attacked by individual extremists, but above all by collectively acting right-wing radicals, often also using various weapons or in combination with arson (ibid.). Violence is also used within one's own group - to reduce frustration but also to punish and discipline one's own comrades - as well as to consolidate the status of one's own group or to expand it in relation to other groups (ibid.). In addition to the violence often exercised in a group-dynamic, these perpetrators tend to have a fundamental affinity and willingness to use violence, which manifests itself in aggressive behavior in childhood and adolescence. Sometimes acts of violence also form the goal and/or focus of a "successful day" (ibid.). In this sense, for some, violence even forms the center of attraction to the right-wing scene. As is the case for all the herein analyzed characteristics, this description does not apply to all right-wing extremist, although corresponding behavior could be observed in many of them. Non-violent persons also join right-wing groups, which then exercise their ideology, for example, through (online) hate speech against foreigners and asylum seekers or denial of the Holocaust (ibid.).

\section{Substance $(A b) u s e^{13}$}

Consuming alcohol and to some extent other drugs plays a major role in the right-wing extremist spectrum. Especially in connection with group activities and/or the use of violence alcohol is consumed (in large quantities) and sometimes acts as a catalyst for subsequent actions (Meyer, 2022; Möller, 2022). This leads to many (occasionally even all) crimes being committed under the influence of alcohol (Meyer, 2022; Möller, 2022). In addition to the consumption of alcohol, the subjects report that illegal drugs also play a role in the right-wing extremist spectrum (although less widespread than alcohol), especially cannabis, but also amphetamines, heroin, or cocaine (Möller, 2022); the interviewed

\footnotetext{
13 Listed in Evls (Ullrich et al., 2019) as "substance issues" [German: "Substanzproblematik"]; substance use is also contained in "Risk taking behaviour" in IVP (see Egan et al., 2016).
} 
experts point to the smoking of cannabis in isolated instances but overall consider illegal drugs to be of much lesser importance than alcohol (see Meyer, 2022). Apart from the overall excessive consumption of alcohol, the interviewed experts were able to clearly diagnose alcohol addiction only in isolated cases and pointed out that they were largely unable to assess whether an addiction was present or not. Only one group of experts mentioned more frequent addiction problems among right-wing extremists (ibid.).

Relating to religiously motivated radicalization, experts frequently report conspicuous drug use (mostly smoking cannabis products) (Meyer, 2022). However, while in the area of right-wing extremism, experts sometimes establish a direct (causal) connection between substance use and extremist acts, such a connection can only be inferred in exceptional cases for the Islamist spectrum (ibid.). Many experts attributed drug use to a general lack of orientation and stability of the persons concerned and often observed it rather in the runup to radicalization (ibid.). The widespread assumption that consumption patterns decline in the course of religious radicalization has been confirmed by a number of experts (ibid.). One possible explanation for the decline was also addressed in interviews with (formerly) radicalized individuals: a change in drug use behavior due to pressure exerted by group members or the threat of being expelled from the group if one continues to consume (see Möller, 2022). However, some experts also reported that many of the people they observed continued to consume despite (outwardly displayed) radicalization, so that no regular pattern can be assumed here (see Meyer, 2022). Apart from very few isolated cases, no addiction problems were observed among persons on the Islamist spectrum, respectively, experts stated they were unable to assess the presence of addiction (ibid.).

\section{Motivation}

\section{Search for Belonging ${ }^{14}$}

According to expert descriptions, many Islamist radicals are people with low self-confidence who have experienced rejection and exclusion, not so much because of their faith or origin but because of their personality. Some of them are characterized by experts as outsiders or loners who can hardly or not at all integrate themselves into social structures; many only acquire social contacts after they entered the Salafi scene (see Meyer, 2022).

(Former) radicalized individuals described experiences of discrimination and/or stigmatization which strengthened or initiated the feeling of lack of belonging (see Möller, 2022). However, exclusion does not always require a specific event. Rather, the interviewees also mentioned as a detriment to inclusion their different appearance or origin (both in the sense of migration background and in the sense of moving houses within Germany).

Feelings of aloneness and exclusion are often compensated by consuming alcohol and/ or drugs (Möller, 2022). A possibility to find the longed-for connection is offered by radical groups (ibid.). A pre-existing lack of social integration makes people receptive to promises of acceptance and security but also to promises of emotional, spiritual, and material support. As part of something bigger, the individual can develop a new and better self-image and find satisfaction and love but also a place of refuge (ibid.). The image of a substitute

${ }^{14}$ Contained in indicators with different emphasis or combination: "Need for identity, meaning, belonging" and "Need for excitement, comradeship or adventure" in ERG22 + (Lloyd and Dean 2015) as well as "motivated by camaraderie, group affiliation" in VERA-2R (Pressman et al., 2018; Sadowski et al., 2017) and as the flip side "unfulfilled need for appreciation/recognition" [German: "Unerfülltes Bedürfnis nach Wertschätzung/Anerkennung"l in EvIs (Ullrich et al., 2019). 
family is repeatedly brought up across ideologies (Meyer, 2022; Möller, 2022). The need to find a home, a "real family," is all the stronger the more difficult the conditions within the family of origin are. The bond to the group - the new family — can be so strong that the family of origin pales in comparison to it and in some cases is even outright rejected by the radicalized individual: "I am giving you an ultimatum. Either the family or you can stay where you are.' And normally one would say yes, I choose the family, but in that moment, I said 'No, I'm staying with the group' because it was my family for me (ID021)."

The internet and social media can play an important role in the search for belonging. They offer the opportunity to network beyond local boundaries, perhaps even to find likeminded people for the first time ever and no longer feel alone. The online world enables contacts that might not have been feasible otherwise. They can then be integrated into "real world life," e.g., through mutual visits or joint events (see also Höffler et al., 2020).

\section{Susceptibility to Influence ${ }^{15}$}

Some experts believe that people on the path of radicalization are characterized by "suggestibility" and a certain "receptiveness" to indoctrination (see Meyer, 2022). Ultimately, such receptiveness exists as a mirror image of the search described under "Identity problems" and the "Search for belonging" in combination with "Intolerance of Ambiguity." Experts described this receptiveness in the Salafi spectrum as an important factor in the initial phase of radicalization (ibid.). In the interviews with (formerly) radicalized individuals, an actual, strong influence from outside could also be determined in many right-wing radical biographies (Möller, 2022). The individuals described emulating (older) group members and adapting their external appearance. Such influence affects behavior and status of the emulating individual ("They made you, yes, you the small one, yes, they made such a fighter out of you, within the scene, right. Such a real soldier, yes" (ID034)), as well as changes their views and emotions ("Yes, you get brainwashed" (ID020)).

\section{Expressing Grievances and/or Fighting Injustices ${ }^{16}$}

Another motivational factor for joining a radical group or for (further) identifying with an ideology can be the need to express grievances and/or to fight injustices.

According to experts, (perceived) injustice and grievances in the context of religiously motivated radicalization processes are less attributed to actual, personal experiences of discrimination rather than expressions of general grievances such as injustice in the Muslim world or the unjust treatment of Muslims in the West (see also "Politicization") (Meyer, 2022). Similarly, injustices and grievances are also felt in right-wing extremism. Particularly frequently, (formerly) radicalized individuals pointed out a perceived preference for "the foreigners." At the same time, a stereotypical image is drawn up, one in which they bring crime to Germany but are yet better treated and more mildly sentenced by the

\footnotetext{
15 Similarly, "Susceptibility to indoctrination" in ERG 22+(Lloyd and Dean 2015) and "Susceptible to influence, authority and indoctrination" in VERA-2R (Pressman et al., 2018; Sadowski et al., 2017).

16 Similarly, "Need to redress injustice and express grievance" in ERG 22 + (Lloyd and Dean 2015); "Perceived injustice and/or grievances" and "Frustration, anger, hate related to perceived alienation or persecution" in VERA-2R (Sadowski et al., 2017); also partly "Personal grievance and moral outrage" in TRAP-18 (Meloy 2017; Meloy et al., 2015), and "Moral outrage due to violence in Muslim world" [German: "moralische Entrüstung aufgrund von Gewalt in muslimischer Welt"] in EvIs (Ullrich et al., 2019); according to Cook, Hart, and Kropp (2013), perceived injustice is also part of the indicator "Negative attitudes toward out-group" in MLG.
} 
criminal justice system compared to "the Germans"; added to this is an ideologized fear of mixing "races" and/or cultures (see Möller, 2022).

As a solution to the recognized injustices, radicalized individuals often demanded a tougher crackdown, calling for the killing of the "problem causer" (be it "the foreigner," "the child molester," "the politician" or the "infidel," "the Jew," "the American") or for "taking justice into our groups own hands."

\section{Emotions $^{17}$}

The guiding emotions and the emotionalization of political issues are formative in the radicalization process. Although external events (see "Politicization") may be "triggers" and promote or bring to light extremist attitudes, the origin of attitudes and opinions is usually to be found on an emotional level (Meyer, 2022). Particularly interviews with (formerly) radicalized individuals revealed emotions such as hate, frustration, and anger-mostly in connection with fantasies of violence or concrete actions; frustration is often relieved by means of violent acts, and one's own sense of well-being is restored through physical superiority (cf. Möller, 2022). Hate and rage were focused on the one hand towards clearly defined outgroups (see "Devaluation of the outgroup and enemy image construction"), towards religions or a certain forms of government ("we were also hateful towards democracy" (ID032)) and on the other hand focused specifically towards certain individuals (ibid.). In this context, fear of the foreign (xenophobia) can also increase feelings of insecurity and injustice and turn into anger or rage. Especially "the inactivity" of the other persons/society leads to anger and the decision to act (ibid.). Such described pre-existing feelings can multiply and be refined in group settings. But they may also be triggered by the radical group in the first place: "Yes, I hate foreigners, I was kind of brought up to hate them" (ID018).

The emotions described are often connected with bad experiences, insults, or (perceived) disadvantages and are therefore often mixed with the perceived injustice or grievances highlighted in the previous section. Moreover, experts increasingly pointed out that rhetorically versed ideologues are able to put these emotions into words and use them specifically for recruitment (Meyer, 2022). At the level of responsiveness (see "Susceptibility for influence"), the mechanism resulting from intolerance of ambiguity (see "Intolerance of ambiguity"), and the emotions interlock.

\section{Inner Attitude and Value System}

\section{Intolerance of Ambiguity ${ }^{18}$}

The inability of extremist persons to endure unclear, ambiguous, or contradictory situations (German "Ambiguitätsintoleranz," Miliopoulos, 2018) is well known in extremism research and can also be confirmed as a relevant radicalization characteristic on the basis of the Göttingen study. The attitudes and the value systems of extremists always rely on clear

\footnotetext{
17 Partly in "Expression of emotions as reaction to perceived injustice" (Pressman et al., 2018)/"Frustration, anger, hate related to perceived alienation or persecution" in VERA-2R (Sadowski et al., 2017) and in its "sister" instrument CYBERA "Moral emotions: hate, anger, frustration, persecution, and/or alienation" (Pressman and Ivan 2016).

18 Also listed in EvIs (Ullrich et al., 2019).
} 
positions ("I am against foreigners/Jews/the state"; see also "Politicization" and "Ideologically fueled rhetoric") and "black and white thinking": the division into good and evil, into in-group and out-group (national vs. foreigner; Muslim vs. non-Muslim; "right Muslims" vs. "wrong Muslims"). In the Islamist spectrum, such attitudes are also communicated in rigid and one-sided statements on political action, especially political conflicts (e.g., the Middle East conflict).

The interviews with both radicals and experts revealed that there is also an increased need for a role model, for regimentation and authority within the radicalization process (Meyer, 2022; Möller, 2022). Recruiters and propaganda provide clear answers and instructions, self-contained, simple worldviews with a claim to absoluteness, thus satisfying the need for unambiguity resulting from intolerance of ambiguity. Through the process of identification with such offers (see also "Identification with group and/or ideology"), a cycle is set in motion that further reduces the possibility of accepting other perspectives and intensifies the process of radicalization (Meyer, 2022).

\section{Devaluation of the Outgroup and Enemy Image Construction ${ }^{19}$}

During the interviews, experts repeatedly noted, and (formerly) radicalized individuals showed the devaluation of the outgroup and the construction of an enemy image based on simplified black-and-white thinking (cf. Meyer, 2022; Möller, 2022).

In the Salafi-Jihadist spectrum, other Muslims—even one's own family—are considered to follow a false faith and are pejoratively labeled "infidels." The absolute superiority of the in-group is emphasized: "For me, the others were not actual humans" (ID021). A moral superiority of the own group is also proclaimed towards "the West." Characteristics of the corruption and moral decay of the West are the acceptance of homosexuality and prostitution, excessive drug use, and the general permissiveness and tolerance of morally unacceptable behavior (Möller, 2022).

In right-wing radicalized views, migrants are the primary target of devaluation, even targeted dehumanization. They are uniformly portrayed as uneducated, unclean, and "social parasites" who bring crime, drugs, and chaos to Germany: "Above all, the majority of crime comes from foreign citizens. That is a fact" (ID032). In the "more harmless" cases, migrants are expected to be exuberantly grateful to be allowed into Germany (cf. Möller, 2022). More often, however, they are dehumanized, put on the same level as animals or called "abnormal." Their lives are worth nothing in the eyes of right-wing extremists, and they are often generally characterized as terrorists. A similar picture is sketched of people who think differently in political terms: they, too, are "dirty", unkempt criminals and are insulted as "leftist ticks" and "social misfits" (ibid.). Moreover, marked by particular hatred are anti-Semitic expressions and characterizations of "the Jews" (see also "Ideologically fueled rhetoric"): "because this fucking capitalist Jew is simply the plague of the world, this ugly animal" (ID026). As a consequence, the "eradication" of Jews - as "the morning

\footnotetext{
19 "Enemy image construction" [German: "Feindbildkonstruktion"] as an indicator in EvIs (Ullrich et al., 2019); included also in "Dehumanisation of the enemy" in ERG22 + (Lloyd and Dean 2015) and also part of "Hate rhetoric" in IVP, according to Cole et al., 2016; the concept of In-and-Outgroup can be found in "Negative attitudes toward out-group" in MLG (Cook, Hart and Kropp 2013), "Us and them thinking" in ERG22 + (Lloyd and Dean 2015), "Lack of empathy, understanding outside own group" in VERA-2R (Pressman et al., 2018; Sadowski et al., 2017), as well as in "Rejection/Devaluation of non-Muslims and other Muslims" [German: "Ablehnung/Abwertung von Nicht-Muslim*innen," "Abwertung anderer Muslim*innen"] in EvIs (Ullrich et al., 2019).
} 
sport of a different kind" (ID034) — but also of sex criminals who are morally and humanly "on the lowest level" is openly advocated for.

\section{Politicization $^{20}$}

Constructions of the enemy image, emotions, and perceived grievances intertwine and constitute the extremists' value system by means of politicization. According to this study's understanding, political questions are thus not the starting point for radicalization, but emotions under the "cloak" of politicization represent a further step forward in the process of radicalization (Meyer, 2022).

Common narratives used for politicization which express feelings of injustice often appear in conjunction: On the Islamist spectrum, actual or perceived discrimination and the "moral indignation due to violence in the Muslim world" (cf. Ullrich et al., 2019) are combined with hostility towards the state (cf. also "Devaluation of the outgroup and construction of the enemy image") and expressed in aggressive rhetoric (see "Ideologically fueled rhetoric"). On the right-wing spectrum presumed discrimination in the labor market and the alleged criminal threat posed by foreigners, who at the same time are favored by judiciary and state merge with anti-Semitism, conspiracy theories and the same hostility and rhetoric mentioned above.

In many cases, perceived injustice is compounded by a need to express these grievances (see also "Expressing grievances and/or fighting injustices"). Especially in the right-wing extremist spectrum, this takes the form of political activism (through organizing and/or participating in protests as well as membership in and support of right-wing political parties, in some cases even taking of political offices, cf. Möller, 2022). Such political activities, e.g., participation in protests were observed at a lesser rate by experts among Islamists (at least in Germany) (Meyer, 2022): only a small subset of Islamist extremists are undertaking them, based, however, rather on their opposition to the state than based on religious motivation. Apart from this, "political" activism is largely limited to the dissemination of online Islamist content and the recruitment activities for Islamist organizations (ibid.).

\section{Advocacy of Extremist Violence ${ }^{21}$}

With increasing radicalization, the ideological content conveyed may result in advocacy of the use of violence against members of the outgroup (see "Devaluation of the outgroup and construction of the enemy image"). According to experts, this advocacy for the use of force seems to be the rule in Islamist radicalization processes but less so in relation to specific persons rather than in relation to groups of people (against Jews; against non-Muslims; against the West; advocacy of the establishment of the Islamic State and the violent implementation of its goals) (Meyer, 2022). Such advocacy, however, does not necessarily lead

\footnotetext{
${ }^{20}$ Also listed as an indicator in EvIs (Ullrich et al., 2019) [German: "Politisierung"]; with a different focus partly also "political activism" in IVP (Cole et al., 2016; Egan et al., 2016) and "Political/moral motivation" in ERG22 + (Lloyd and Dean 2015).

21 Similarly "Advocacy/justification of religiously motivated violence" [German: "Befürwortung/Rechtfertigung von religiös motivierter Gewalt" in EvIs (Ullrich et al., 2019) and "Commitment to ideology justifying violence" in VERA-2R (Pressman et al., 2018; Sadowski et al., 2017); according to Meloy and Gill 2016 with respect to the justification of the terrorist's intent to act also comprised by "Framed by an ideology" in TRAP-18.
} 
to the use of violence by oneself (ibid.). Thus, this is different and to be distinguished from the ideological justification of one's own criminal acts and violence.

In contrast, interviews with (formerly) radicalized people showed that "in-group-outgroup thinking" in right-wing radicalism is usually accompanied by the targeted use of violence against those who think differently and against foreigners (Möller, 2022). This is partly due to the internalized ideology of the victims' inferiority. But sometimes the violent acts' motivating factor is not even of an ideological nature, rather the focus is on the mere opportunity for (howsoever justified) violence (keywords here are spontaneous violence and enjoyment of violence) (ibid.). In the right-wing extremist spectrum, therefore, the boundaries of "advocacy for extremist violence" become more blurred towards an "ideological justification of one's own violent and criminal acts."

\section{Ideological Justification of One's Own Violence and Crimes ${ }^{22}$}

For Islamist radicals, the use of ideology_or at least selected narratives - to legitimize one's own crimes can be distinguished from the general support for extremist violence. According to experts particularly those who belong to the Islamists subset with conspicuous criminal records (see "Delinquency and substance (ab)use") argue that criminal acts against infidels are justified (be it the use of violence, drug sales, or property offenses), in some cases pointing to the argument of "if it serves the good cause" (see Meyer, 2022). This finding complements the conclusion on the propensity to violence in the Islamist spectrum (see "Delinquency and substance (ab)use"): Individuals who have already before their radicalization been prepared to use violence find justification for their actions in extremist ideology (ibid.). The same can be said for right-wing extremism. Nevertheless, there are also violent offenders on the right-wing spectrum who were not violent before their radicalization. These individuals' change of delinquency pattern is attributable to their new worldview which now ideologically justifies previously rejected violent acts (cf. Möller, 2022).

\section{Identification with Group and/or Ideology ${ }^{23}$}

Identification with a group and/or ideology is less about the group and ideology itself rather than the process of identification and its possible effects on all areas of life (cf. Möller, 2022). "It was my purpose in life. It was not just a phrase, it was my everything/ it was not just a mindset, it was a calling. [...] it was my whole life philosophy" (ID034). Both one's own needs and previous contacts can be completely subordinated to the group and/or ideology. Contacts to friends are broken off, and one's family is left behind (see also substitute family under "Search for belonging")—-the group comes first, everything else is no longer important. "It concerns every area of life, what you do, how you do it, who you are friends with, contact with the opposite sex, with the state, society, family, everything is regulated, so to speak" (ID019) (ibid.). In addition to a strict religious structuring of the

\footnotetext{
${ }^{22}$ Similarly, "religious justification of criminality" [German: "Religiöse Rechtfertigung von Kriminalität"] in EvIs (Ullrich et al., 2019); presumably also included in "attitudes that justify offending" in ERG $22+($ Lloyd and Dean 2015).

${ }^{23}$ Similarly, also "overidentification with a group or cause" in ERG 22 + (Lloyd and Dean 2015); identification process partly also addressed by "personal grievance and moral outrage" in TRAP-18 where "moral outrage is typically a vicarious identification with a group which has suffered" according to Meloy and Gill 2016.
} 
day (e.g., through prayer times), the group's expectations and demands for constant availability, and thus also the willingness to be there for the group at all times, determine one's daily schedule (ibid.). Habits, views, and behaviors are accordingly shaped by and adapted to the (new) world view (e.g., concerning sexuality or consumer behavior) (ibid.).

Occasionally, the interviewed experts, too, reported such mechanisms (cf. Meyer, 2022). Experts on Islamist extremism mentioned social withdrawal, especially from family members (ibid.). The interviews with (formerly) radicalized individuals of both ideologies occasionally revealed a "vacuum" of social contacts that could then be filled by contacts with radical individuals or groups (Möller, 2022). On the other hand, however, many radicalized persons continue to be integrated into their family and circles of friends-in some cases, they are already growing up in "radical structures" so that a vacuum does not arise in the first place, in other cases, the non-radicalized social contacts continue to exist simultaneously (ibid.).

\section{Masculinity Ideals ${ }^{24}$}

In the interviews with persons from the right-wing extremist spectrum, clear gender role models characterized by ideals of masculinity emerged: the man as provider on the one hand and the housewife on the other hand (cf. Möller, 2022). Two stereotypes of women were drawn up: (1) the woman as the weaker sex, dependent on the man, subservient to him, and begging for his attention, and (2) the woman as a style icon, who must pay attention to etiquette and elegance and thereby increases the self-esteem and reputation of the man towards the outside world. In contrast to this, men see themselves as the savior and protector of women, as the "strong sex," who must not show any weakness (ibid.). Fights are part of the life of a real man, and dominance is expressed through violence (ibid.). Masculinity and deprecation of women are further expressed when giving reasons for why women (including those in the outgroup) must not be beaten: this is considered cowardly, because "a woman [...] unable to defend herself is like a child, in need of protection" (ID020).

The patriarchal interpretation of Islam also plays a role in the religiously motivated spectrum, especially among young individuals in search of identity (see "Identity issues"). It manifests in an exaggerated need to express masculinity (Meyer, 2022; Möller, 2022). At the same time, radicalized individuals reprimand women in their social environment (especially sisters, but also mothers, etc.) to adhere to religious gender roles and duties of a good Muslim woman. Within male-dominated radical groups, women have to take the position of "housekeepers." As in the right-wing radical spectrum, women are declared "weak" and in need of male protection. "Well, they were allowed to sit there and listen, but they were not allowed to say anything" (ID021) (see Möller, 2022).

\section{Behavior}

\section{Identification Through Symbolism ${ }^{25}$}

Both in the radical right-wing and in the Salafi-Jihadist spectrum, internal attitudes are often externally displayed (Möller, 2022, see also Meyer, 2022). Especially in the Islamist

\footnotetext{
${ }^{24}$ Similarly, "Patriarchal gender concepts “ [German: "patriarchalische Geschlechtervorstellungen”) in EvIs (Ullrich et al., 2019).

${ }^{25}$ Partly similar "Use of relevant ideological symbols" [German: "Verwendung einschlägiger ideologischer Symbole"] in EvIs (Ullrich et al., 2019) and "Uses graphic representations, symbols/logos of terrorist groups, steganography" in CYBERA (Pressman and Ivan 2016).
} 
spectrum, visible changes can regularly be observed in the course of the radicalization process. In addition to the haircut (very short or bald in the right-wing extremist spectrum) or beard (obligatory in the Salafi-Jihadist spectrum), the style of clothing adapts, too; in the Salafi-Jihadist spectrum in particular, the following applies: bans on European clothing, role model: Mohammed; in the right-wing extremist spectrum: bomber jackets, combat boots (cf. Möller, 2022). Symbolic meanings can also be integrated into one's external appearance. Tattoos often express the inner world view in the right-wing scene, either clearly recognizable for everyone or requiring special background knowledge (ibid.). Experts described the criminally relevant use of unconstitutional symbols as one of the most frequent offenses, especially, but not only, in the right-wing extremist spectrum (see Meyer, 2022).

According to expert observations, in addition to the Salafi outer appearance, adaptation also takes place in behavioral patterns, such as the exaggerated use of salutations, excessive praying, and a certain uncompromising attitude with regard to religion (Meyer, 2022). In some cases, such behavior is also supposed to be used intentionally to provoke others and to satisfy an excessive need for attention and recognition (ibid.). All Salafi-Jihadist (formerly) radicalized individuals that were interviewed, too, described that their turning to a Salafi-Jihadist interpretation of Islam was accompanied by a change in live style habits and behavior (cf. Möller, 2022).

\section{Consuming Ideologically Relevant Material ${ }^{26}$}

Closely linked to the radicalization process is consuming ideologically relevant materials. The internet, including social media, is the main source (see Höffler et al., 2020). This applies in particular to the Salafi-Jihadist spectrum, where concrete "online-fatwas" as well as Salafist/Jihadist writings and videos are spread and subscribed to online (cf. Möller, 2022). Furthermore, discussions about religious issues and current events take place in forums and chats with like-minded individuals. In the radical right-wing spectrum, increasing radicalization also often goes hand in hand with an increasing importance of consuming ideologically relevant content online (ibid.). The radical individual's world views are thereby not just shared with like-minded people but also externally displayed, e.g., through public comments or remarks in the comment section of daily newspapers (ibid.).

Music is of particular importance both specifically for individuals and groups (see Meyer, 2022; Möller, 2022). Music reaches the recipient on an emotional level and can strengthen or even create a feeling of togetherness through shared experiences, whether through concerts or spending time together: "well, then you go join the guys, drink five beer and sing German songs" (ID032). It is well known in academic literature and is confirmed by our interviews with (formerly) radicalized individuals that music appeals to the political self-image of the listeners (Dornbusch \& Raabe, 2005): "you simply identify with the music in some way" (ID033). Song texts offer dichotomized, simple solutions for a (too) complex world (see also "Intolerance of ambiguity"). Music thus serves as a "means of transporting extremist worldviews" (see Mischler \& Möller, 2020; Möller \& Mischler,

\footnotetext{
26 Similarly, "Consumption and/or distribution of relevant content" [German: "Konsum und/oder Verbreitung einschlägiger Inhalte"] in EvIs (Ullrich et al., 2019); comprised by "Seeker, consumer, developer of violent extremist materials" in VERA-2R (Pressman et al., 2018; Sadowski et al., 2017); also several indicators in CYBERA (Pressman and Ivan 2016), e.g., "Uses graphic representations, symbols/logos of terrorist groups, steganography," "Uses musical background to incite hatred, recruitment to violent action," and "Repetitively accesses posts blogs, extremist forums, terrorist information, know-how.".
} 
2021). The repeat consumption of strongly ideologized music can lead to an internalization of lyrics (Büchner, 2018) and the narratives transported within them, especially if musicians are revered as role models and/or heroes: "These are role models, [...] many of them expressed exactly what I felt" (ID026).

Both experts and (formerly) radicalized individuals mentioned that radicalization occasionally includes not just consuming but also creating and disseminating ideologically relevant content (Meyer, 2022; Möller, 2022).

\section{Ideologically Fueled Rhetoric $^{27}$}

Radicalized people express their attitudes (cf. "Inner attitude and value system") through ideologically fueled rhetoric. In accordance with the narratives described above, the interviews with (formerly) radicalized individuals showed the integration of ideologically coined terms and slogans-e.g., "infidels," "master race," "blood and honor," as well as linguistic generalizations and insults into everyday language (cf. Möller, 2022): In the radical right-wing spectrum, the adoption of such phrases is to some extent accompanied by historical revisionist lines of reasoning, glossing over German history, and decriminalizing it. Salafi-Jihadist lines of reasoning, on the other hand, rely primarily on religious norms and demands - no alcohol, no music — as well as threats, "eternal punishment" and "retribution"; such statements are often linked to ideologized hatred and/or the justification or glorification of violence (ibid.). In some cases, this even reaches the extent of a deathrhetoric - talking about the use of "bombs" and "hand grenades" for the "mortal enemy" or defending borders with "machine guns"- which characterizes the current situation as a state of war (cf. Möller, 2022).

Experts very often observed anti-Semitic statements and conspiracy theories in both ideological spectrums. The images of the enemy discussed under "politicization" drawn up by radicalized individuals are strongly verbalized (for example, see "Devaluation of the outgroup and enemy image construction").

\section{Missionary Work and Reprimanding the Social Environment ${ }^{28}$}

(Formerly) radicalized interviewees across both ideologies displayed continued efforts on the one hand to missionize and recruit their social environment and on the other hand to regulate and reprimand ideologically undesired behavior in others (Möller, 2022). Experts, too, occasionally reported witnessing missionizing and reprimanding, e.g., towards fellow prisoners in custody but also in direct contact towards the experts themselves (see Meyer, 2022).

According to right-wing and religiously motivated radicalized individuals converting family, relatives, friends, acquaintances, and work colleagues to "true" Islam or to join the radical group or the attempt to do so occasionally constituted the concrete goal or the concrete task of the individual in the group (cf. Möller, 2022). In most cases, these efforts

\footnotetext{
27 Contained in several indicators of CYBERA (Pressman and Ivan 2016), especially "personal, terrorist narrative to promote extremist views, aggression, grievances" and "Uses language to display extremist views, allegiance to terrorist group, narrative"; also in rhetoric related indicators of EvIs (Ullrich et al., 2019) "relevant statements/catchphrases" [German: "Einschlägige Äußerungen/Phrasen"] and "anti-Semitic statements"; similarly also IVP (Cole et al., 2016; Egan et al., 2016) with indicators "Violent rhetoric" and "Death rhetoric.".

28 Also listed in EvIs [German: "Missionierung/Reglementierung des sozialen Umfelds"] (Ullrich et al., 2019).
} 
were aimed at people personally acquainted with the recruiting radical—not least to reduce the risk of "traitors," "informers," and "merely nosy persons" (ibid.). To achieve greater success, manipulative techniques were also learned or adopted: "We were also good at it, weren't we? Well, this manipulative thing, I could also do it quite well, right? Train the little ones until, well, they took part, painting their ideal enemy image for them, right" (ID034). The social environment is also judged and reprimanded according to the groups' ideological values (ibid.). Family and friends who do not fit into the groups' world view are despised, sometimes even threatened with punishment (ibid.).

\section{Psychological Features}

\section{Self-Promotion and Need for Recognition ${ }^{29}$}

The interviewed experts often noticed an exaggerated need for recognition and the urge for self-promotion in extremists (cf. Meyer, 2022): This is evident in the Salafi-Jihadist spectrum, for example, in excessive religious self-promotion and provocations (see also "Identification through symbolism"), the staging of photos with weapons, or even bragging about a (planned) departure to a combat zone. Self-worth is increased through being respected or at least seen by others; occasionally narcissistic personalities or such tendencies are mentioned by the experts (ibid.). Interestingly, such self-promotion was also sometimes described as a characteristic of persons who do not use violence themselves, who merely advocate or propagate it, and who "do not want to get their hands dirty" and rather act or want to act as spokesperson and leader ("would-be preachers") (ibid.).

Likewise, many interviewed (formerly) radicalized individuals from the right-wing extremist spectrum have been found to have a grandiose self-image (cf. Möller, 2022). This can refer to physical strength and fitness (important for acts of violence), professional and financial success and (as a result) successes with women (see also "Ideals of masculinity"), the number of friends and acquaintances, but also intellect and other special abilities (ibid.). Occasionally, (personal) contact with known persons/extremists/terrorists is also emphasized in order to increase one's own importance through association with their "celebrity" (ibid.).

\section{Identity Issues ${ }^{30}$}

Mentioned particularly often by experts are identity issues among young Salafists (Meyer, 2022) — probably not least a result of judgmental observation on the experts' side. The lack of being able to satisfy one's needs, especially within the family, but also life paths of failure, marked by educational underperformance and even crime, lead to an apparent lack

\footnotetext{
29 Similar aspects in "Need for identity, meaning, belonging" and "Need for status" in ERG (Lloyd and Dean 2015), "Motivated by acquiring status" and "Striving for meaning and significance in life" in VERA-2R (Pressman et al., 2018, Sadwoski et al. 2017); as the flip side "Unfulfilled need for appreciation/ recognition" [German: "Unerfülltes Bedürfnis nach Wertschätzung/Anerkennung"] in EvIs (Ullrich et al., 2019).

${ }^{30}$ Listed as "Identity crisis" [German: "Identitätskrise"] in EvIs (Ullrich et al., 2019); also aspects of "Uses multiple/alternative narratives related to identity," "Frequently changes profile and cover photos - inconsistent identity," and "Identity conflict, rejection of national collective identity" in CYBERA (Pressman and Ivan 2016); again also contained in indicators with different emphasis or combination, like in "Need for identity, meaning, belonging" in ERG22 + (Lloyd and Dean 2015) and in "Striving for meaning and significance in life" in VERA-2R (Pressman et al., 2018; Sadowski et al., 2017).
} 
of orientation, stability, and meaning (ibid.). This is mirrored in the search for meaning in life and search for one's own identity, i.e., the leitmotif and driving force behind almost all processes of radicalization. Further occasionally reported by experts as causes for identity problems are inner conflicts regarding one's nationality as a (not necessarily Muslim) migrant and being confronted with one's Islamic religion and the need to justify oneself in the context of it in Western society. In ideology these "identity seekers" find what they are looking: receive answers, a connection, a role, or even the opportunity to be someone (ibid.).

\section{Mental Health ${ }^{31}$}

Special attention must also be paid to the mental health of extremist individuals. Some experts reported on mentally ill radicalized people but mostly emphasized the exceptional nature of such illness (cf. Meyer, 2022). The observed characteristics covered a wide range of mental abnormalities and disorders. More frequently mentioned characteristics include trauma, anti-social disorders, and depression, as well as narcissistic disorders or character traits (ibid.). In addition, a few experts also mentioned schizophrenia, autism and Asperger's, obsessive-compulsive disorder, personality disorder, delusion, neuroses, ADHD, and psychopathy. Among the interviewed (formerly) radicalized individuals, some showed signs of depression, ADHD, borderline personality disorder, post-traumatic stress disorder, or combinations of these (cf. Möller, 2022).

\section{Group Dynamics and Influences ${ }^{32}$}

The fact that group dynamics and influences have a decisive impact on thinking and behavior was described in detail by (formerly) radicalized interviewees across all ideologies (see also Möller, 2022): The "search for affiliation" can pave the way to a radical group. Standing up for one another, mutual help and support ("Whoever needed help, got help. If there were problems somewhere, we went there, solved them" (ID014)) can create or strengthen a close bond with the group and at the same time exert strong attraction; furthermore, the group stands for "honorable" principles perceived as meaningless in the "outside world" and mainstream society (ibid.). In addition, however, these groups also have group norms that advocate violence, to which all members must adapt, or which may be in line with members' already pre-existing propensity towards violence (see also "Criminal history" and "Ideological justification of one's own violence and crime") (ibid.). On the one hand, these norms' effect within the group is to maintain the group's hierarchy, punish dissenters, or determine the status of group members. On the other hand, group norms advocating violence also lay an important foundation for acts of violence against the outgroup or rival groups (ibid.). Particularly in combination with ideology, a critical questioning of violence and the reasons given for it is often lacking, and violent actions become normalized: "If we saw a leftist tick, we just beat it up. That's just the way it was" (ID026). For some

\footnotetext{
31 Also listed as such in ERG 22+(Lloyd and Dean 2015); similarly, "Mental health problems" in MLG (Cook, Hart, and Kropp 2013, Hart et al., 2017) and "Psychological abnormalities" [German: "Psychische Auffälligkeiten"] in EvIs (Ullrich et al., 2019) and "Mental disorders" in TRAP-18 (Meloy 2017; Meloy et al., 2015); VERA-2R covers "Mental disorders" in "Additional indicators" (Pressman et al., 2018).

32 Similarly, "Group influence and control" in ERG22 + (Lloyd and Dean 2015) and especially to be found in various indicators of MLG (Cook, Hart, and Kropp 2013; Hart et al., 2017), e.g., "Strong group-based identity," "Strong commitment to group," and "Violent norms or goals.".
} 
individuals, joint violent actions also satisfy a general need for violence, dominance, and adrenaline and/or are perceived as "great fun" and a euphoria inducing group experiences; in extreme cases even one's own life is subordinated to the group's cause: "a lot of injuries happened, huge lacerations, fractures of the base of the skull, stabbings, we often had that, didn't we. That a comrade simply fell down and didn't get up again. Trampled to death, beaten to death" (ID034).

\section{Societal Radicalizing Factors ${ }^{33}$}

Societal factors can also influence individual radicalization processes by providing possible triggers for turning one's attention in a certain direction or for strengthening pre-existing thought patterns. Both (formerly) radicalized persons and experts repeatedly named as examples of such national and international sociopolitical factors the refugee crisis as well as political changes, terrorist attacks, and international warfare (Meyer, 2022; Möller, 2022). The effects of such events are often felt on an individual level and can cause strongly emotional reactions (see also "Emotions"). Thus, societal upheavals can on the one hand generate xenophobia (see Höffler \& Sommerer, 2017) ("And now, during the refugee crisis, things have gotten even worse. Of course, the greatest fear is directed towards all the refugees" (ID017)). On the other hand, they can be a confirmation of an already existing sense of injustice ("For me the best example [...] New Year's Eve in Cologne. [...] if some German guy had done that, he would have been sentenced to years in prison for touching women. And just because it's a foreigner like that, he'll be released" (ID017)). But societal events can also be the trigger for turning ones' attention towards concrete problems in the world ("the trigger was the war, a coup in Egypt, this military coup in Egypt, where the democratically elected president was then overthrown by the military and the world watched and somehow I had the impression that everyone is relieved that this Muslimbrother is now no longer in power" (ID010)). In the course of this, an individual is then confronted with ideologically shaped patterns of reasoning which may then be integrated into their own world view (Möller, 2022).

\section{Discussion and Conclusion}

\section{Discussion}

The findings presented here are based on the analysis and comparison of already existing risk assessment tools as well as on a qualitative evaluation of our interviews conducted with experts and (formerly) radicalized individuals. Moreover, for the analysis of interviews with (formerly) radicalized individuals, Social Network Analysis (SNA) was employed. Expert interviews per design only provide filtered observations and cannot provide the same direct access to information as interviews with radicalized individuals themselves. Since access to (formerly) radicalized persons as interview partners is extremely difficult on the one hand (see Lützinger, 2010; Möller, 2022) and since on the other hand experts have knowledge of a large number of radicalized persons qua profession, our expert

\footnotetext{
${ }^{33}$ Societal factors are only considered by the "Group-Societal" set of indicators in MLG (Cook, Hart and Kropp 2013, Hart et al., 2017 for MLG version 2) although with a different focus than found in the present study.
} 
interviews concentrated on said "collected" knowledge. Particularly with regard to the interviews with (formerly) radicalized persons and the sensitive topics addressed therein (e.g., xenophobia and radical attitudes), a bias in response behavior due to the phenomenon of social desirability cannot be eliminated in this study either. By the absence of third parties in the interview, strict promises of anonymity and thus at the same time the assurance that no consequences-whether positive or negative-would result from what was said for the interviewee, as well as refraining as far as possible from a (negative) judgment of what was said by the interviewer, an attempt was made to keep these distortions as low as possible.

The juxtaposition of these data sources provided a multi-faceted picture; it was precisely by contrasting the experts' data with the (formerly) radicalized subjects' descriptions that a more differentiated picture of the radicalization processes could be painted.

As already mentioned in the "Methodology" section, this paper's predominant focus was on radicalization relevant variables which emerged as circumstances of special importance from a qualitative content-analytical evaluation of both expert interviews as well as interviews with (formerly) radicalized individuals. For some of these radicalization relevant variables, the results of interviews with experts and (formerly) radicalized individuals strongly diverged. For instance, educational and vocational failures (indicator of the item "lack of pro-social integration," MLG) were remarkably frequently described by experts but were not confirmed by the (formerly) radicalized individuals or at least presented in a different light. This is probably due in particular to the differences in self-perception and perception by others. Addressing these differences, however, was not focused on in this paper. Rather, this example is intended to demonstrate the diversity and complexity of radicalization processes. Likewise, deradicalization processes were addressed in the interviews, but their examination would exceed the scope of this article.

Mental disorders were not identified as a key factor for radicalization both in the interviews with (formerly) radicalized individuals as well as with experts. However, the fact that it was nevertheless repeatedly observed and reported should alert to the relevance of mental disorders existing in parallel, i.e., next to a radicalization process. ${ }^{34}$

The variables that have emerged in our research rarely stand side by side in isolation but are often strongly interwoven; many variables exhibit multiple links; frequently the same theme appears in multiple interlocking criteria (e.g., anti-Semitism in "Enemy image construction", "Politicization" and "Ideologically fueled rhetoric"). The particular challenge is - as is the case with all prognosis tools - to capture such interactions and multiplexity in a (dimensionally limited) format. This can be seen not only in the complexity of the various variables' relationships but is also reflected in the different set-ups and objectives of already existing risk assessment tools (see already above; for a detailed analysis, see Meyer, 2022).

A particular challenge for the future progress in risk assessment research also arises from difficulties of the quantitative evaluation of risk assessment tools (few, hard to access radicalized individuals distributed globally; the objectives and fields of application of the tools are very diverse (reaching from early detection to treatment planning)). Exchange between agencies ("intelligence analysts know everything but understand nothing," Sageman, 2014) and researchers (“...while academics understand everything but know nothing," Sageman, 2014) as well as concerted, international cooperation among researchers

\footnotetext{
${ }^{34}$ When working with extremist (violent) criminals, special attention must therefore always be paid to mental health, if necessary with the help of specific instruments.
} 
in this field would certainly be welcomed and lead to greater progress (as a good starting point, see the joint directory of tools also referred to in this paper in Lloyd, 2019), although data protection concerns in this explosive research field present hurdles with respect to research data. Past approaches at such cooperation probably failed not because of researchers' lack of motivational but because of institutional constraints; for example, the RADARITE instrument developed for Germany's Federal Bureau of Investigation is still classified, to name just one example.

Our analysis has further revealed an important aspect of existing extremist risk assessment tools, which has so far been paid too little attention: variables pointing towards radicalization are often variables already well-known from prognosis tools for general crime (e.g., substance abuse; breaks; criminal history); this parallel should be given greater focus in the further development of extremism specific tools.

\section{Conclusion}

In a desire to provide hands-on operability for risk assessment practitioners, and to create synergies that have so far been left unexplored (given the fragmented nature of existing risk assessment tools), our research resulted in a structured list of radicalization process characteristics (see Table 1). We thus combined the scattered wisdom of multiple pre-existing risk assessment tools with our own research into one easy to follow list of characteristics, the ARISNA: "Assessment of Radicalized Individuals including Social Network Analysis." Starting with an individual's biography, the practitioners' focus is guided towards inter alia upbringing and previous experience of victimization. What follows are inter alia the area "criminal history and substance (ab)use." In addition, significant behavioral patterns carried in the outside world can be distinguished from the inner attitudes and values as well as motivations. According to our results, an important area that has been neglected or not sufficiently structured in pre-existing research and tools are an individual's contacts. Therefore, what is new-especially in terms of method-is the integration of the method of social network analysis in the risk assessment. We emphasize that the method of social network analysis, which helps capture the social context in a structured and precise way, provides important additional support in this respect but has so far been under-utilized in radicalization research and practice and has prior to our research never been integrated into any risk assessment work (but see the foundational work of Rau, 2017 as well as on the use of Rau \& Höffler, 2020). Social Network Analysis (SNA) allows a structured approach to the survey of social contacts. At the same time, it offers the potential to enrich other listed variables, e.g., "difficult upbringing," with further useful information. Thus, it is an important addition, which we recommend to any radicalization researcher and/or practitioner if time and other resources are available. The moment at which the SNA is carried out may vary according to need-e.g., as a preventive measure in the run-up to radicalization or to support deradicalization.

Also to be considered are psychological features. Referring to MLG, group dynamics and influences and the relationship to society, i.e., "socio-political changes or events," should also be taken into account.

The list presented here is expressly not intended to produce a one-dimensional risk score; this is partly due to the problems of quantitative evaluation described above but also because we posit that a score of this kind is inevitably under-complex when it 
Table 1 ARISNA: Assessment of Radicalized Individuals including Social Network Analysis

\begin{tabular}{|c|c|}
\hline Biography & $\begin{array}{l}\text { Difficult upbringing } \\
\text { Victimization experiences } \\
\text { Losses and breaks }\end{array}$ \\
\hline Social contacts & $\begin{array}{l}\text { Contact to other radicalized person(s) } \\
\text { Social Network Analysis (SNA)• }\end{array}$ \\
\hline \multicolumn{2}{|l|}{ Criminal history and substance (ab)use } \\
\hline Motivation & $\begin{array}{l}\text { Search for belonging } \\
\text { Susceptibility to influence } \\
\text { Expressing grievances and/or fighting injustices }\end{array}$ \\
\hline \multicolumn{2}{|l|}{ Emotions } \\
\hline Inner attitude and values system & $\begin{array}{l}\text { Intolerance of ambiguity } \\
\text { Devaluation of the outgroup and enemy image construction } \\
\text { Politicization } \\
\text { Advocacy of extremist violence } \\
\text { Ideological justification of one's own violence and crime } \\
\text { Identification with group and/or ideology } \\
\text { Masculinity ideals }\end{array}$ \\
\hline Behaviors & $\begin{array}{l}\text { Identification through symbolism } \\
\text { Consuming ideologically relevant material } \\
\text { Departure (attempt) to combat zones } \\
\text { Ideologically fueled rhetoric } \\
\text { Missionary work and reprimanding social environment }\end{array}$ \\
\hline Psychological features & $\begin{array}{l}\text { Self-promotion and need for recognition } \\
\text { Identity issues } \\
\text { Mental health }\end{array}$ \\
\hline \multicolumn{2}{|l|}{ Group dynamics and influences } \\
\hline Societal radicalizing factors & \\
\hline
\end{tabular}

-The SNA helps to record information on a large number of variables in a structured manner, not only for "social contacts," but also for other indicators on the list that have links to the social network.

comes to human behavior. Rather, the entire biography of the person and the dynamics of many factors, i.e., their changeability, must be considered. This ARISNA is therefore intended to provide an opportunity to keep track of the various interlocking aspects of the radicalization processes, and thus also to serve as a support tool for practitioners, to foster a better understanding of the individual and their environment in the context of radicalization.

The complexity of capturing each individual case of radicalization becomes apparent by analyzing the different life courses; therefore, it cannot be pointed out often enough that merely ticking off boxes and adding up risk factors cannot lead to satisfactory results. The practitioners should therefore always have the dynamics of the individual life course in mind: one factor can change everything in individual evaluations, turning preliminary conclusions upside down (Bock, 2017; Nedopil, 2006).

Acknowledgements This article was written as part of the joint project "Radicalization in the Digital Age - risks, developments and strategies of prevention" (RadigZ), funded by the German Federal Ministry of Education and Research under the funding code 13N14285. See also http://www.radigz.de.

Funding Open Access funding enabled and organized by Projekt DEAL. Bundesministerium für Bildung und Forschung, Förderkennzeichen 13N14285. 
Availability of data and material No, because of the sensitivity of the data and the data protection concept.

Open Access This article is licensed under a Creative Commons Attribution 4.0 International License, which permits use, sharing, adaptation, distribution and reproduction in any medium or format, as long as you give appropriate credit to the original author(s) and the source, provide a link to the Creative Commons licence, and indicate if changes were made. The images or other third party material in this article are included in the article's Creative Commons licence, unless indicated otherwise in a credit line to the material. If material is not included in the article's Creative Commons licence and your intended use is not permitted by statutory regulation or exceeds the permitted use, you will need to obtain permission directly from the copyright holder. To view a copy of this licence, visit http://creativecommons.org/licenses/by/4.0/.

\section{References}

Beelmann, A. \& Lehmann, L. (2020). Radikalisierung im digitalen Zeitalter. Handlungsempfehlungen an Politik, Praxis und Gesellschaft. Kurzfassung. Hannover: Kriminologisches Forschungsinstitut e.V.

Bidart, C., \& Charbonneau, J. (2011). How to generate personal networks: Issues and tools for a sociological perspective. Field Methods, 23(3), 266-286.

Bock, M. (1984). Kriminologie als Wirklichkeitswissenschaft. Duncker \& Humblot.

Bock, M. (2008). 4. Teil. Angewandte Kriminologie. In H. Göppinger, Kriminologie (pp. 248-344). München: C.H. Beck.

Bock, M. (2017). Kriminologie. Verlag Franz Vahlen.

Büchner, T. (2018). „Weltbürgertum statt Vaterland“. Antisemitismus im RechtsRock. Münster: edition assemblage.

Bundeskriminalamt (BKA), Bundesamt für Verfassungsschutz (BfV), \& Hessisches Informations- und Kompetenzzentrum gegen Extremismus (HKE) (2016), Analyse der Radikalisierungshintergründe und -verläufe der Personen, die aus islamistischer Motivation aus Deutschland in Richtung Syrien oder Irak ausgereist sind. Fortschreibung 2016. https://www.bka.de/SharedDocs/Downloads/DE/Publikatio nen/Publikationsreihen/Forschungsergebnisse/2016AnalyseRadikalisierungsgruendeSyrienIrakAusrei sende.html. Accessed 7 January 2021.

Burt, R. (1984). Network items and the general social survey. Social Networks, 6(4), 293-339.

Campbell, K., \& Lee, B. A. (1991). Name generators in surveys of personal networks. Social Networks, 13, 203-221.

Cole, J., Alison, E., Cole, B., \& Alison, L. (2016). Guidance for identifying people vulnerable to recruitment into violent extremism. https://preventforfeandtraining.org.uk/wp-content/uploads/2017/09/IVP_ Guidance_Draft_v0.3_web_version.pdf. Accessed 7 January 2021.

Cook, A. N. (2014). Risk assessment and management of group-based violence. Simon Fraser University.

Cook, A. N., Hart, S. D., \& Kropp, P. R. (2013). Multi-level guidelines (MLG); for the assessment \& management of group-based violence; User Manual. Burnaby, British Columbia, Canada: Mental Health, Law, And Policy Institute (MHLPI).

Dahle, K.-P. (2010). Psychologische Kriminalprognose. Wege zu einer integrativen Methodik für die Beurteilung der Rückfallwahrscheinlichkeit bei Strafgefangenen (2nd ed.). Centaurus Verlag.

Dornbusch, C., \& Raabe, J. (2005). Rechtsrock fürs Vaterland. In A. Röpke, \& A. Speit (Ed.), Braune Kameradschaften. Die militanten Neonazis im Schatten der NPD (pp. 67-86). Berlin: CH. Links Verlag.

Egan, V., Cole, J., Cole, B., Alison, L., Alison, E., Waring, S., \& Elntib, S. (2016). Can you identify violent extremists using a screening checklist and open-source intelligence alone. Journal of Threat Assessment and Management, 3(1), 21-36.

Flick, U. (2011). Triangulation. Eine Einführung. VS Verlag für Sozialwissenschaften.

Gill, P. (2015). Toward a scientific approach to identifying and understanding indicators of radicalization and terrorist intent: Eight key problems. Journal of Threat Assessment and Management, 2(3-4), $187-191$.

Göppinger, H. (1983). Der Täter in seinen sozialen Bezügen: Ergebnisse aus der Tübinger Jungtäter-Vergleichsuntersuchung. Springer.

Granovetter, M. S. (1974). Getting a job: A study of contact and careers. Harvard Univ. Pr.

Guldimann, A., \& Meloy, J. R. (2020). Assessing the threat of lone-actor terrorism: The reliability and validity of the TRAP-18. Forensische Psychiatrie, Psychologie, Kriminologie, 14(2), 158-166.

Hart, S., Cook, A., Pressman, E., Strang, S. \& Lim, Y. (2017). A concurrent evaluation of threat assessment tools for the individual assessment of terrorism. Canadian Network for Research on Terrorism, 
Security Ans Society (TSAS). http://www.tsas.ca/wp-content/uploads/2018/03/2017-01-Hart-WP-1. pdf. Accessed January 7.

Herzog-Evans, M. (2018). A comparison of two structured professional judgment tools for violent extremism and their relevance in the French context. European Journal of Probation, 10(1), 3-27.

Höffler, K., \& Sommerer, L. (2017). Biedermann und die Brandstifter. Kriminologische Überlegungen aus aktuellem Anlass. Monatsschrift für Kriminologie und Strafrechtsreform, 100(1), 26-44.

Höffler, K. \& Gatzmaga, F. (2018). Die Bedeutung des persönlichen Nahbereichs radikalisierter Personen für die Risikoprognose. In Boers, K. \& Schaerff, M. (Eds.), Kriminologische Welt in Bewegung. Neue Kriminologische Schriftenreihe der Kriminologischen Gesellschaft (pp. 168-178). Mönchengladbach: Forum Verlag Godesberg.

Höffler, K., Meyer, M., \& Möller, V. (2020). Die Rolle sozialer Kontakte (online/offline) im Radikalisierungsprozess. In Grafl, C., Stempkowski, M. \& Beclin, K. (Eds.), Sag wie hast du's mit der Kriminologie? Die Kriminologie im Gespräch mit ihren Nachbardisziplinen. Neue Kriminologische Schriftenreihe der Kriminologischen Gesellschaft (pp. 437-455). Mönchengladbach: Forum Verlag Godesberg.

Kuckartz, U. (2018). Qualitative Inhaltsanalyse. Methoden, Praxis, Computerunterstützung. Winheim: Beltz.

Lloyd, M., \& Dean, C. (2015). The development of structured guidelines for assessing risk in extremist offenders. Journal of Threat Assessment and Management, 2(1), 40-52.

Lloyd, M. (2019). Extremist risk assessment: A directory - full report. Center for Research and Evidence on Security Threats (CREST). https://crestresearch.ac.uk/resources/extremism-risk-assessmentdirectory/. Accessed 7 January 2021.

Lützinger, S. (2010). Die Sicht der Anderen. Eine qualitative Studie zu Biographien von Extremisten und Terroristen. Luchterhand.

Mayring, P. (2015). Qualitative Inhaltsanalyse: Grundlagen und Techniken. Beltz.

Meloy, J. R., Hoffmann, J., Guldimann, A., \& James, D. (2012). The role of warning behaviors in threat assessment: An exploration and suggested typology. Behavioral Sciences \& the Law, 30(3), 256-279.

Meloy, J. R., \& Yakeley, J. (2014). The violent true believer as lone wolf psychoanalytic perspectives on terrorism. Behavioral Sciences \& the Law, 32(3), 347-365.

Meloy, J. R., Roshdi, K., Glatz-Ocik, J., \& Hoffmann, J. (2015). Investigating the individual terrorist in Europe. Journal of Threat Assessment and Management, 2(3-4), 140-152.

Meloy, J. R., \& Gill, P. (2016). The lone-actor terrorist and the TRAP-18. Journal of Threat Assessment and Management, 3(1), 37-52.

Meloy, J. R. (2017). TRAP-18. Terrorist radicalization assessment protocol. User Manual. North Tonawanda, NY: Global Institut of Forensic Research.

Meyer, M. (2022). Extremistische Devianz und Risikobewertung (forthcoming).

Miliopoulos, L. (2018). Ursachen für politischen Extremismus (Kapitel VI). In E. Jesse, \& T. Mannewitz (Eds.), Extremismusforschung - Handbuch für Wissenschaft und Praxis (pp. 205-243), BadenBaden: Nomos.

Mischler, A., \& Möller, V. (2020). Der Soundtrack des Extremen - Naschids und RechtsRock als Transportmittel extremistischer Weltanschauung. In Boers, K. \& Schaerff, M. (Eds.), Kriminologische Welt in Bewegung. Neue Kriminologische Schriftenreihe der Kriminologischen Gesellschaft (pp. 803-824). Mönchengladbach: Forum Verlag Godesberg.

Möller, V. (2020). Bedeutung und Nutzen der egozentrierten Netzwerkanalyse in der Radikalisierungsforschung. Ein Werkstattbericht zum Einsatz der Methode. Monatsschrift für Kriminologie und Strafrechtsreform, 103(2), 158-168.

Möller, V. (2022). Biografie- und Netzwerkforschung zu Radikalisierungsverläufen. Zugleich ein Beitrag zur Prognoseforschung (forthcoming).

Möller, V., \& Mischler, M. (2021). The soundtrack of the extreme. Nasheeds and Right-Wing Extremist Music as a 'Gateway Drug' into the Radical Scene. International Annals of Criminology 59(1) (in press).

Monahan, J. (2012). The individual risk assessment of terrorism. Psychology, Public Policy, and Law, $18(2), 167-205$.

Monahan, J. (2017). The individual risk assessment of terrorism: Recent developments. In Lafree, G. \& Freilich, J. (Eds.), The Handbook of the Criminology of Terrorism (pp. 520-534). Chichester, West Sussex: Wiley-Blackwell.

Nedopil, N. (2006). Prognosen in der Forensischen Psychiatrie - Ein Handbuch für die Praxis. Lengerich a.o.: Pabst Science Publishers.

Powis, B., Randhawa-Horbe, K., Elliot, I., \& Woodhams, J. (2019). Inter-rater reliability of the Extremism Risk Guidelines 22+ (ERG 22+), Ministry of Justice, UK. https://assets.publishing.service.gov. 
uk/government/uploads/system/uploads/attachment_data/file/839726/inter-rater-reliability-extre mism-risk-guidelines.pdf. Accessed 7 January 2021.

Powis, B., Randhawa, K., \& Bishopp, D. (2019b). An examination of the structural properties of the extremism risk guidelines (ERG22+): A structured formulation tool for extremist offenders. Terrorism and Political Violence. https://doi.org/10.1080/09546553.2019.1598392

Pressman, E., Duits, N., Rinne, T., \& Flockton, J. (2018). VERA-2R. Violence Extremism Risk Assessment - Version 2 Revised. Ein Ansatz zur strukturierten professionellen Beurteilung.

Pressman, E. (2009). Risk assessment decisions for violent political extremism, Her Majesty the Queen in Right of Canada. https://www.publicsafety.gc.ca/cnt/rsrcs/pblctns/2009-02-rdv/2009-02-rdv-eng. pdf. Accessed 7 January 2021.

Pressman, E., \& Flockton, J. (2012). Calibrating risk for violent political extremists and terrorists: the VERA 2 structured assessment. The British Journal of Forensic Practice, 14(4), 237-251.

Pressman, E., \& Ivan, C. (2016). Internet use and violent extremism: A Cyber-VERA Risk Assessment Protocol (Chapter 19). In M. Khader, L. Seng Neo, G. Ong, E. T. Mingyi, \& J. Chin (Eds.), Combating Violent Extremism and Radicalization in the Digital Era (pp. 391-409). Hershey, Pensilvania: IGI Global.

Rau, M. (2017). Lebenslinien und Netzwerke junger Migranten nach Jugendstrafe. Ein Beitrag zur Desistance-Forschung in Deutschland. Lit Verlag Dr. W. Hopf.

Rau, M., \& Höffler, K. (2020). Soziale Netzwerkanalyse in der deutschsprachigen Kriminologie: Vorhandenes Herausforderungen und Potentiale. Kriminologie-Das Online-Journal, 2(1), 7-38.

RMA: Scottish Risk Management Authority (2019). https://www.rma.scot/wp-content/uploads/2019/09/ RATED_TRAP-18_July-2019_Hyperlink-Version.pdf. Accessed 7 January 2021.

Sadowski, F., Rossegger, A., Pressman, E., Rinne, T., Duits, N., \& Endrass, J. (2017). Das Violent Extremism Risk Assessment Version 2 Revised (VERA-2R). Kriminalistik-Schweiz, 2017, 335-342.

Sageman, M. (2014). The stagnation in terrorism research. Terrorism and Political Violence, 26(3), 465-580.

Scarcella, A., Page, R., \& Furtado, V. (2016). Terrorism, radicalisation, extremism, authoritarianism and fundamentalism: A systematic review of the quality and psychometric properties of assessments. PLoS ONE. https://doi.org/10.1371/journal.pone.0166947

Ullrich, S., Nabo, M. M., Nehlsen, I., \& Armborst, A. (2019). EvIs: Evaluationskriterien für die Islamismusprävention (Handbuch), Nationales Zentrum für Kriminalprävention (NZK) https://www.nzkrim. de/fileadmin/nzk/content/EvIs/EvIs_Handbuch.pdf. Accessed 7 January 2021.

Publisher's Note Springer Nature remains neutral with regard to jurisdictional claims in published maps and institutional affiliations. 